\title{
The osmotic concept of the intracranial pressure
}

\author{
Herbowski L* \\ Neurosurgery Department District Hospital, Arkonska 4, 71-455 Szczecin, Poland
}

\section{Introduction}

For the first time the intracranial pressure (ICP) in humans was recorded as pulsatile curve by Giacomini and Mosso in 37-year-old woman with syphilitic infection in 1876 [1]. Nowadays, ICP recording is widely used in neurosurgery and neurointensive units. Although the intraventricular pressure monitoring is the "gold standard", there are some indirect and non-invasive routes to estimate the value of the intracranial pressure. The main alternative methods are: visual evoked potentials, phase-contrast magnetic resonance, transcranial Doppler, tympanic membrane displacement, intraocular pressure and acoustoelasticity.

Historically, in the 1960s Davson's concept of the intracranial pressure was based on the balance between formation and absorption of the cerebrospinal fluid leading to the simple equation:

$\mathrm{ICP}=0.3 \mathrm{x}$ resistance + Pressure Venous.

(Formula 1)

Ten years later the extended intracranial dynamics concepts were presented by Marmarou et al. and Avezaat \& Eijndhoven [2,3], reflected by the non-linear relationship:

$$
\mathrm{ICP}=\mathrm{P}_{1} \mathrm{e}^{\mathrm{Vcc} /(0.4343 \times \mathrm{PVIcc})}+\mathrm{P}_{0} .
$$

Even though more and more sophisticated mathematical models of ICP physics enable to determine ICP based on cerebral hemodynamics, additional clinical data is needed to validate these methods [4-6]. Despite these many possibilities of assessing the value of ICP, the scientific literature lacks the studies concerning the mechanisms driving ICP. Therefore, I present a precise molecular concept of the intracranial pressure genesis.

Intracranial osmotic homeostasis and osmotic approach to ICP genesis: The cerebrospinal fluid is surrounded tightly by completely impermeable arachnoid membrane on the outer side and semipermeable membrane composed of glial cells and neurons on the inner side. The main cation in the cerebrospinal fluid is sodium $\left(\mathrm{Na}^{+}\right)$and the main anion is chloride $\left(\mathrm{Cl}^{-}\right)$. The following ions are present in the cerebrospinal fluid but in much lower concentrations: $\mathrm{HCO}_{3}, \mathrm{Ca}^{2+}$. The rest of organic and non-organic ions are omitted in further analysis due to significantly lower concentrations. There is a dynamic equilibrium between intracellular and extracellular ions defining chemical gradient between both compartments. And this difference in pressure of the two compartments is the osmotic pressure $(\Delta \Pi)$ of solutes. The passive distribution of water across the biological semi-permeable membrane is a thermodynamic consequence of solutes distribution. In closed and rigid cranium, the change of compartmental volume will lead to a pressure difference. Given dynamic equilibrium between compartments, the osmolality of the fluid is the same within the cell and in the cerebrospinal fluid, although the concentration of each ion is not equal. Both compartments are in a stationary osmotic state. Water flow via membrane could be stopped by equivalent hydrostatic pressure of water volume. This blocking pressure is just the osmotic pressure.

The osmotic pressure is expressed by the classical van't Hoff equation [7]

$$
\Delta \mathrm{P}=\Delta \Pi=\mathrm{R} \times \mathrm{T} \times \Delta \mathrm{C},
$$

(Formula 3)

where $\Delta \mathrm{P}$ is the difference in hydrostatic pressure, $\mathrm{R}$ is ideal gas constant $(8.31 \mathrm{~J} / \mathrm{mol} \mathrm{x} \mathrm{K}), \mathrm{T}$ is the body temperature in Kelvins $\left(37^{\circ} \mathrm{C}\right.$ $\left.=310.15^{\circ} \mathrm{K}\right), \Delta \mathrm{C}$ is the difference in molar concentration of solutes.

Thus, the osmotic gradient between inner and outer environment of the glial/neuronal cells is a difference between the most prominent ions of the cerebrospinal fluid and their content inside the cells.

Calculation of the cerebrospinal fluid osmotic pressure: To estimate osmotic pressure between the cerebrospinal fluid and glial/ neuronal cytoplasm the above Formula 3 is used. The gradient of solute concentration $\Delta \mathrm{C}$ (the difference between the chosen chemical concentration of most common ions across the glial and neuronal semipermeable membrane) is demonstrated in Table 1. Ions concentrations in brain were set based on published data [8-11].

In summary, the gradient of solute concentration in the cerebrospinal fluid compared to astrocytes and neurons is $249.42 \mathrm{mM}$ and $270.15 \mathrm{mM}$, respectively. Since the ratio of glia to neuron in human brain is 1:1, both of these compartments have to be taken into account when calculating the total osmotic pressure of the cerebrospinal fluid [12]. Therefore, when calculating the total gradient, the following formula is used

$$
\Delta \mathrm{C}=1 / 2 \Delta \mathrm{C}_{\mathrm{CSF} / \text { Glial }}+1 / 2 \Delta \mathrm{C}_{\mathrm{CSF} / \text { Neuron' }}
$$

from which we obtain $\Delta \mathrm{C}=259.785 \mathrm{mM}$.

And thus, the total cerebrospinal fluid osmotic pressure, using the Formula 3, is 669.56 Pa.

Table 1. Ions composition of the cerebrospinal fluid, astrocyte and neuron cytoplasm in human

\begin{tabular}{|c|c|c|c|c|c|}
\hline Ions & $\begin{array}{c}\text { Cerebrospinal } \\
\text { Fluid }\end{array}$ & $\begin{array}{c}\text { Glial } \\
\text { Cytoplasm }\end{array}$ & $\begin{array}{c}\text { Neuronal } \\
\text { Cytoplasm }\end{array}$ & $\begin{array}{c}\text { Cerebrospinal } \\
\text { Fluid/Glia }\end{array}$ & $\begin{array}{c}\text { Cerebrospinal } \\
\text { Fluid/Neuron }\end{array}$ \\
\hline $\mathrm{Na}^{+}$ & $147 \mathrm{mM}$ & $15 \mathrm{mM}$ & $10 \mathrm{mM}$ & $132 \mathrm{mM}$ & $137 \mathrm{mM}$ \\
\hline $\mathrm{Cl}^{-}$ & $132 \mathrm{mM}$ & $30 \mathrm{mM}$ & $6.6 \mathrm{mM}$ & $102 \mathrm{mM}$ & $125.4 \mathrm{mM}$ \\
\hline $\mathrm{HCO}_{3}^{-}$ & $23.3 \mathrm{mM}$ & $11 \mathrm{mM}$ & $18 \mathrm{mM}$ & $12.3 \mathrm{mM}$ & $5.3 \mathrm{mM}$ \\
\hline $\mathrm{Ca}^{+2}$ & $3.2 \mathrm{mM}$ & $80 \mathrm{nM}$ & $0.75 \mathrm{mM}$ & $3.12 \mathrm{mM}$ & $2.45 \mathrm{mM}$ \\
\hline
\end{tabular}

${ }^{\star}$ Correspondence to: Leszek Herbowski MD, PhD, Neurosurgery Department District Hospital, Arkonska 4, 71-455 Szczecin, Poland, E-mail: leszek@ herbowski.eu

Received: March 01, 2019; Accepted: April 19, 2019; Published: May 03, 2019 
The hydrostatic pressure of cerebrospinal fluid is $6.8 \mathrm{~cm} \mathrm{H}_{2} \mathrm{O}(5.02$ $\mathrm{mmHg}$ )

\section{Future directions}

Macroscopic studies are insufficient to determine precisely the intracranial homeostasis. The issue of fluids' transmembrane penetration needs investigation on atomic level. The further diffusion analysis across the border of so many intracranial compartments should be performed. And there is also an electrochemical potential of compositions, which is an important driving force of ions' and biomolecules' movement, requiring determination of its role in the generation of the intracranial pressure.

\section{Conclusion}

The intracranial pressure can be defined as the pressure of the cerebrospinal fluid enclosed in cranium and spine. The pressure of cerebrospinal fluid is exerted against impermeable arachnoid membrane on outer side and glial/neuronal semi-permeable membrane on inner side. According to thermodynamic principles, the osmotic pressure between the cerebrospinal fluid and astrocyte/neuron cytoplasm across the glial/neuronal membrane is the driving force of hydrostatic pressure within the cerebrospinal fluid compartment. And this hydrostatic pressure is just the intracranial pressure. In normal condition - transmembrane equilibrium - the value of the intracranial pressure is about $7 \mathrm{~cm} \mathrm{H}_{2} \mathrm{O}$. The osmotic approach constitutes the first such attempt to describe ICP origin.

\section{Authorship and contributorship}

Author's contribution: research concept and design, collection and assembly of data, data analysis and interpretation, writing the article, critical revision of the article, approval of the article.

\section{Conflict of interest}

The author declares that he has no conflict of interest.

\section{Acknowledgment}

The author thanks Patrycja Herbowska-Tytro for help in the English translation and final preparation of the paper in terms of lexis and grammar.

\section{Funding information}

No funding was received.

\section{Competing interest}

The author declares that he has no competing interest.

\section{References}

1. Giacomini C, Mosso A (1876) Esperienze sui movimenti del cervello nell'uomo. Arch Sci Med 1: 245-278.

2. Marmarou A, Shulman K, LaMorgese J (1975) Compartmental analysis of compliance and outflow resistance of the cerebrospinal fluid system. J Neurosurg 43: 523-534. [Crossref]

3. Avezaat CJ, van Eijndhoven JH (1986) Clinical observations on the relationship between cerebrospinal fluid pulse pressure and intracranial pressure. Acta Neurochir (Wien) 79: 13-29

4. Ursino M, Lodi CA (1997) A simple mathematical model of the interaction between intracranial pressure and cerebral hemodynamics. J Appl Physiol 82: 1256-1269. [Crossref]

5. Wang JX, Hu X, Shadden SC (2019) Data-augmented modeling of intracranial pressure. Ann Biomed Eng 47: 714-730.

6. Wagshul ME, Eide PK, Madsen JR (2011) The pulsating brain: A review of experimental and clinical studies of intracranial pulsatility. Fluids Barriers CNS 8: 5.

7. Evans DH (2008) Osmotic and Ionic Regulation: Cells and Animals. CRC Press.

8. Somjen GG (2004) Ions in the Brain. Normal function, Seizures, and Stroke. Oxford University Press.

9. Rose CR, Verkhratsky A (2016) Principles of sodium homeostasis and sodium signaling in astroglia. Glia 64: 1611-1627.

10. Hajjawi OS (2014) Human brain biochemistry. American Journal of BioScience 2: 122 134

11. Irani DN (2008) Cerebrospinal Fluid in Clinical Practice. Elsevier Health Sciences.

12. Von Bartheld CS, Bahney J, Herculano-Houzel S (2016) The search for true numbers of neurons and glial cells in the human brain: A review of 150 years of cell counting. $J$ Comp Neurol 524: 3865-3895. [Crossref]

Copyright: $@ 2019$ Herbowski L. This is an open-access article distributed under the terms of the Creative Commons Attribution License, which permits unrestricted use, distribution, and reproduction in any medium, provided the original author and source are credited. 